JIKAP PGSD: Jurnal Ilmiah Ilmu Kependidikan

Vol,4. No,1. Tahun 2020

e-ISSN: 2597-4440 dan p-ISSN: 2597-4424

(c) (1) This work is licensed under a Creative Commons Attribution

4.0 International License

\title{
Pengembangan Instrumen Penilaian Kinerja (Performance Assessment) Praktikum Konsep Dasar IPA Berbasis Karakter Untuk Mengukur Kemampuan Proses Sains Mahasiswa PGSD Fakultas Ilmu Pendidikan Universitas Negeri Makassar
}

\author{
Muhammad Irfan', Muslimin ${ }^{2}$ \\ 1,2 PGSD FIP UNM \\ Email: 1irfanunm@gmail.com \\ 2 muslimin61@yahoo.co.id
}

\begin{abstract}
Abstrak. Penelitian ini merupakan penelitian pengembangan yang bertujuan untuk menghasilkan instrumen penilaian kinerja praktikum Konsep DasarIPA berbasis Karakter untuk mengukur Kemampuan proses sains Mahasiswa PGSD FIP UNM. Secara khusus Intrumen penilaian kinerja yang dihasilkan adalah instrument kinerja praktikum IPA untuk menilai Kemampuan Proses Sains IPA Mahasiswa PGSD FIP UNM. Hasil penilaian pakar/ahli dan praktisi untuk menilai kesesuaian antar materi, konstruksi, dan bahasa pada setiap butir-butir instrumen penilaian menunjukkan bahwa perangkat yang telah dikembangkan telah memenuhi kriteria valid dan reliabel. Hasil simulasi dan uji keterbacaaan menunjukkan bahwa instrumen dapat terbaca dan terpahami dengan jelas oleh pemakai sehingga dapat digunakan untuk menilai kinerja praktikum Mahasiswa. Hasil uji kefektifan menunjukkan bahwa; (1) data tentang respon Dosen (teman sejawat) terhadap perangkat penilaian kinerja praktikum (uji keterbacaan) berada pada kategori sangat baik; (2) hasil lembar pengamatan penggunaan perangkat penilaian kinerja praktikum yang diisi oleh pengamat minimal terlaksana semua, (3) data nilai kinerja praktikum dapat dideskripsikan sesuai dengan kriteria yang dinilai dan, (4) respon mahasiswa terhadap terhadap perangkat pembelajaran (penuntun praktikum) positif. Dengan demikian maka instrumen penilaian kinerja Praktikum Fisika telah memenuhi kriteria valid dan reliabel dan dapat digunakan secara baik efeisien oleh Dosen dan Mahasiswa Prodi PGSD UNM.
\end{abstract}

Kata Kunci: Penilaian Kinerja, Berbasis karakter, Kemampuan Proses Sains

\begin{abstract}
This research is a research development that aims to produce a practical performance assessment instrument of Character-based Basic Concept of Science to measure the ability of the science process of PGSD FIP UNM Students. Specifically, the performance appraisal instruments produced were the performance instruments of the science practicum to assess the ability of the Science Process Science of PGSD FIP UNM Students. The results of the assessment of experts/experts and practitioners to assess the suitability between material, construction, and language on each item of the assessment instrument indicate that the device that has been developed has fulfilled valid and reliable criteria. The results of the simulation and the readability test show that the instrument can be read and understood clearly by the user so that it can be used to assess the performance
\end{abstract}


JIKAP PGSD: Jurnal Ilmiah Ilmu Kependidikan

of the Student practicum. The effectiveness test results show that; (1) data about the lecturers '(colleagues') responses to the practicum performance appraisal (readability test) is in the very good category; (2) the results of the observation sheet using practicum performance appraisal tools filled in by observers minimally carried out all, (3) practicum performance value data can be described in accordance with the assessed criteria and, (4) student responses to positive learning tools (practical guides). Thus, the Physics Practicum performance appraisal instrument has fulfilled valid and reliable criteria and can be used efficiently and efficiently by Lecturers and Students of PGSD UNM Study Program.

Keywords: Performance Assessment, Character-Based, Science Process Capability

\section{PENDAULUAN}

Evaluasi merupakan bagian integral dalam proses pembelajaran, Dosen dituntut untuk merencanakan seluruh rangkaian perkuliahan, mulai dari membuat desain pembelajaran, melaksanakan proses pembelajaran, serta mengevaluasi hasil belajar berupa dampak pengajaran. Proses pembelajaran konsep dasar IPA memaksimalkan integrasi teori dan praktek. Evaluasi memegang peran penting dalam menentukan ketercapaian tujuan pembelajaran di kelas. Masalah yang dihadapi dalam kegiatan praktikum adalah belum tersedianya asesmen yang standar dalam mengevaluasi mahasiswa (Trianto, 2011). Tujuan praktikum adalah untuk mengembangkan keterampilan memecahkan masalah dan berpikir kreatif, meningkatkan pemahaman terhadap sains dan metode ilmiah, mengembangkan keterampilan percobaan dan penyelidikan ilmiah, menganalisis data dan mengkomunikasikan hasil, melatih kemampuan bekerja sama, menumbuhkan sikap positif dan minat, serta meningkatkan pemahaman dan kepedulian terhadap lingkungan.

Selain itu, dosen harus memiliki kemampuan dan keterampilan dasar yang dibutuhkan untuk kelancaran proses belajar mengajar secara efektif dan efesien. Keterampilan dosen dalam proses belajar mengajar antara lain: keterampilan membuka dan menutup pelajaran, keterampilan menjelaskan, keterampilan bertanya, keterampilan memberi penguatan, keterampilan membimbing diskusi kelompok kecil, keterampilan mengelola kelas, keterampilan mengadakan variasi, dan keterampilan mengajar perorangan dan kelompok kecil.

Berdasarkan hasil observasi, penilaian pada praktikum Konsep Dasar IPA di Laboratorium IPA PGSD FIP UNM masih menggunakan sistem penilaian tradisional dimana mahasiswa yang praktikum dinilai melalui respon sebelum praktikum serta laporan yang telah dibuat setelah praktikum. Keadaan ini menjadi sebuah kendala tersendiri dalam melakukan penilaian, mengingat keterbatasan pengamatan dan jumlah mahasiswa yang banyak, sehingga ada kalanya kinerja mahasiswa selama melakukan praktikum kurang terperhatikan dengan baik.

Belum adanya instrumen yang standar untuk mengukur kemampuan proses sains mahasiswa menjadi urgen untuk dilakukan penelitian. Padahal keterampilan proses dapat membentuk intelektual sosial mahasiswa dan mengembangkan lebih lanjut pengetahuan ataupun konsep bagi para mahasiswa (Asiah, 2019). Oleh karena itu, penelitian ini nantinya akan menghasilkan instrumen penilaian kinerja (Performance Assessment) praktikum Konsep Dasar IPA Berbasis Karakter untuk Mengukur Kemampuan Proses Sains Mahasiswa yang bertujuan untuk mengetahui proses pengembangan instrument penilaian kenerja (performance assessment) praktikum IPA berbasis karakter untuk mengukur kemampuan proses sains mahasiswa PGSD, Fakultas Ilmu Pendidikan, Universitas Negeri Makassar dan mengetahui faktor-faktor apa saja yang memengaruhi implementasi instrument penilaian kinerja berbasis karakter pada praktikum IPA di Prodi PGSD, Fakultas Ilmu Pendidikan, Universitas Negeri Makassar

\section{METODE PENELITTIAN}

Penelitian ini merupakan penelitian pengembangan atau Research and Development yang bertujuan untuk mengembangkan instrumen penilaian kinerja praktikum fisika tingkat SMP/MTs dan rubrik penskorannya. Intrumen 
penilaian kinerja praktikum yang dihasilkan adalah instrumen penilaian kinerja untuk menilai kinerja praktikum fisika siswa untuk kegiatan praktikum listrik arus searah yaitu untuk praktikum hukum ohm, rangkaian seri resistor, dan rangkaian paralel resistor. Pengembangan instrumen penilaian kinerja praktikum pada pokok bahasan listrik ini secara konseptual dilakukan melalui proses validasi muka, validasi secara kualitatif dan validasi pakar/ahli. Pada tahap ujicoba instrumen pelaksanaan pembelajaran diupayakan agar kinerja yang akan dinilai dapat muncul dan dapat direkap menggunakan instrumen yang dihasilkan.

Penelitian ini dilaksanakan di Prodi. PGSD FIP UNM, pada kegiatan Parktikum mata Kuliah Konsep Dasar IPA. Instrumen/perangkat yang dikembangkan dalam penelitian ini adalah instrumen/perangkat penilaian kinerja praktikum IPA dan rubrik penskorannya. Untuk memperoleh data secara empiris mengenai pengembangan perangkat instrumen yang akan diteliti, maka digunakan instrumen; 1) instrumen validasi perangkat; 2) angket respon dosen terhadap perangkat penilaian dan rubrik penskorannya dan 3) angket respon Mahasiswa terhadap penuntun praktikum.

Prosedur pengembangan perangkat penilaian kinerja praktikum Konsep Dasara IPA untuk setiap unit kegiatan praktikum adalah; 1) mengkaji RPS, dan Indikator dalam mata Kuliah Konsep Dasar IPA (sains Fisika); 2) menganalisis jenis kegiatan praktikum (keterampilan proses sains) yang dapat dilakukan, hasil analisis menggambarkan bahwa ada tiga unit kegiatan praktikum; 3) mengidentifikasi indikator yang akan dinilai dalam keterampilan proses sains; 4) menyusun perangkat penilaian kinerja praktikum dan rubrik penskorannya; 5) melakukan penilaian pakar/ahli; 6) Menganalisis hasil penilaian pakar/ahli dan melakukan revisi 1 ; 7) melakukan ujicoba pada beberapa orang teman sejawat; 8) melakukan analisis dan melakukan revisi 2 terhadap hasil ujicoba; melakukan ujicoba pada subjek penelitian; 9) analisis dan melakukan revisi 3; merumuskan Instrumen Final, yaitu Perangkat Penilaian Kinerja Praktikum beserta pedoman penskorannya.

Data yang diperoleh dianalisis dengan pendekatan kualitatif dan kuantitatif. Data hasil validasi oleh pakar dianalisis secara kualitatif dengan melihat rata-rata skor total yang diberikan oleh validator.

Data keefektifan perangkat asesmen kinerja praktikum diambil melalui data tentang hasil respon dosen terhadap asesmen kinerja praktikum dan angket respon terhadap perangkat. Kriteria yang digunakan untuk menyatakan penelaah (praktisi) memberikan respon yang memadai adalah skor rata-rata untuk keseluruhan aspek minimal berada pada kategori baik. Jika tidak memenuhi kriteria tersebut, maka perlu dilakukan revisi berdasarkan saran dari responden validator atau dengan melihat kembali aspekaspek yang nilainya kurang. Sedangkan kriteria yang digunakan untuk memutuskan bahwa instrumen penilaian kinerja praktikum memiliki derajat penggunaan yang memadai adalah nilai dan Ai minimal berada dalam kategori terlaksana sebagian. Jika nilai $M$ berada di dalam kategori lainnya, maka perlu dilakukan revisi dengan melihat kembali aspek-aspek yang nilainya kurang.

Reliabilitas hasil lembar pengamatan penggunaan perangkat penilian kinerja praktikum ini diuji dengan rumus sebagai berikut:

$$
\text { Percentage of Agreement }=\left[1-\frac{A-B}{A+B}\right] \times 100 \%
$$

(Borich, 1994: 385)

Instrumen dikatakan baik jika mempunyai koefisien reliabilitas $\geq 0,75$ atau $\geq 75 \%$ (Borich, 1994: 385).

Data yang diperoleh dari hasil penilaian kinerja praktikum ditabulasikan untuk menentukan skor yang diperoleh mahasiswa. Instrumen dikatakan baik jika data kinerja praktikum mahasiswa dapat ditampilkan dan dideskripsikan sesuai dengan kinerja yang dinilai.

Kriteria yang ditetapkan untuk mengatakan bahwa mahasiswa memiliki respons positif terhadap penuntun praktikum adalah, lebih dari $50 \%$ dari mahasiswa memberi respons positif terhadap minimal $70 \%$ jumlah aspek yang ditanyakan. Kriteria yang ditetapkan untuk mengatakan bahwa mahasiswa memiliki respons positif terhadap perangkat rata-rata penilaian mahasiswa terhadap perangkat berada pada kategori baik atau sangat baik

Perangkat di katakan efektif jika memenuhi keempat kriteria yang telah ditetapkan, yang diantaranya adalah; (1) data tentang respon 
teman sejawat terhadap perangkat penilaian kinerja praktikum (uji keterbacaan) berada pada kategori minimal baik; (2) hasil lembar pengamatan penggunaan perangkat penilaian kinerja praktikum yang diisi oleh pengamat minimal terlaksana sebagian; (3) data nilai kinerja praktikum mahasiswa dapat dideskripsikan sesuai dengan kriteria yang dinilai dan; (4) respon mahasiswa terhadap terhadap perangkat pembelajaran (penuntun praktikum) positif

\section{HASIL DAN PEMBAHASAN}

\section{Deskripsi Prosedur Pengembangan Instrumen Penilaian Kinerja Praktikum}

Dari berbagai teori yang dikemukakan di dalam instrumen penilaian kinerja dapat dirumuskan aspek atau kriteria yang akan dinilai dalam kegiatan percobaan hukum ohm, rangkaian seri resistor, dan rangkaian parallel resistor. Indikator yang dimaksud diantaranya adalah; 1) keterampilan pengamatan; 2) keterampilan merangkai alat/bahan; 3) keterampilan dalam pengukuran dan perekaman data; 4) keterampilan membuat tabel; 5) keterampilan menghitung, dan 6) keterampilan komunikasi, yang terdiri dari indikator; 1) kemampuan membuat latar belakang; 2) kemampuan merumuskan masalah; 3) kemampuan membuat tujuan percobaan; 4) kemampuan membuat kajian pustaka; 5) kelengkapan alat dan bahan; 6) membuat prosedur kerja; 7) membuat tabel percobaan; 8) menganalisis data; 9) membuat pembahasan; 10) membuat kesimpulan; 11) membuat saran; dan 12) membuat daftar pustaka.

Berdasarkan indikator yang telah dikemukakan tersebut di atas, maka selanjutnya akan dikembangkan rubrik penskoran penilaian kinerja praktikum, dari indikator-indikator yang telah diuraikan menjadi butir-butir instrumen yang sesuai dengan kebutuhan di lapangan, dan diujicobakan di lapangan.

Ujicoba setiap aspek yang dinilai menunjukkan tercapai tidaknya aspek yang diharapkan muncul. Kemunculan kriteriayang dideskripsikan pada rubrik penskoran yang dibuat dan dapat diidentifikasi melalui kinerja proses yang ditunjukkan. Kinerja proses diidentifikasi melalui pengamatan penilai/observer sehingga dapat dirumuskan hasil dari pengukuran terhadap proses atau prosedur kerja yang ditunjukkan dengan kategori dari sangat baik, baik, kurang baik, sampai denga tidak baik dengan rentang skor (skala penilaian) dari 1 sampai 4.

\section{Deskripsi Hasil Analisis Perangkat Instrumen Penilaian Pakar/Ahli}

Sebelum dilakukan pengujian validitas muka dan telaah butir secara kualitatif pada instrumen penlaian kinerja maka, selanjutnya dilakukan lagi analisis uji pakar/ ahli secara kualitatif terhadap perankat instrumen yang dibuat. Perangkat instrumen penilaian yang divalidasi berupa perangkat isntrumen penilaian kerja, dan rubik penilaian kinerja. Kriteria utama untuk menentukan apakah sebuah perangkat instrumen penilaian layak digunakan atau tidak, bergantung dari hasil validasi pakar/ahli. Untuk mengetahui apakah instrumen yang dikembangkan perlu mendapatkan koreksi dan masukan dari ahli tentang instrumen yang dikembangkan.

Berdasarkan validasi dari pakar/ahli untuk menilai kesesuaian antar materi, konstruksi, dan bahasa pada setiap butir-butir isntrumen penilaian kinerja dengan memberikan skor pada setiap aspek yang dinilai dengan rentang skor dari 1 sampai 4. Hasil perhitungan indeks kesepahaman antara dua validator memberikan nilai $\mathrm{R}=0,96$. Indeks kesepahaman kedua validator terhadap masing-masing perangkat, telah memenuhi kriteria perangkat yang baik yaitu lebih besar dari 0,75. Kedua validator memberikan kesimpulan bahwa perangkat yang telah dikembangkan baik dan dapat digunakan dengan sedikit revisi.

Berdasarkan hasil analisis validitas maka dapat disimpulkan bahwa perangkat penillaian kinerja praktikum hukum ohm menurut penilaian ahli telah memenuhi kriteria kevalidan, dengan kategori sangat baik.Dari penilaian ahli (validasi) diperoleh koreksi, kritik, dan saran-saran yang selanjutnya merupakan bahan pertimbangan untuk merevisi perangkat.Hasil perhitungan indeks kesepahaman antara dua validator memberikan nilai $\mathrm{R}=0,95$. Indeks kesepahaman kedua validator terhadap masing-masing perangkat, telah memenuhi kriteria perangkat yang baik yaitu lebih besar dari 0,75. Kedua validator memberikan kesimpulan bahwa perangkat yang telah dikembangkan baik dan dapat digunakan dengan sedikit revisi.

Berdasarkan hasil analisis validitas maka dapat disimpulkan bahwa perangkat penillaian 
kinerja praktikum rangkaian seri resistor menurut penilaian ahli telah memenuhi kriteria kevalidan, dengan kategori sangat baik.Dari penilaian ahli (validasi) diperoleh koreksi, kritik, dan saransaran yang selanjutnya merupakan bahan pertimbangan untuk merevisi perangkat.

Hasil perhitungan indeks kesepahaman antara dua validator memberikan nilai $\mathrm{R}=0,94$. Indeks kesepahaman kedua validator terhadap masing-masing perangkat, telah memenuhi kriteria perangkat yang baik yaitu lebih besar dari 0,75. Kedua validator memberikan kesimpulan bahwa perangkat yang telah dikembangkan baik dan dapat digunakan dengan sedikit revisi.Berdasarkan hasil analisis validitas maka dapat disimpulkan bahwa perangkat penillaian kinerja praktikum rangkaian paralel resistor menurut penilaian ahli telah memenuhi kriteria kevalidan, dengan kategori sangat baik. Dari penilaian ahli (validasi) diperoleh koreksi, kritik, dan saran-saran yang selanjutnya merupakan bahan pertimbangan untuk merevisi perangkat.

Hasil perhitungan indeks kesepahaman antara dua validator memberikan nilai $\mathrm{R}=0,96$. Indeks kesepahaman kedua validator terhadap masing-masing perangkat, telah memenuhi kriteria perangkat yang baik yaitu lebih besar dari 0,75. Kedua validator memberikan kesimpulan bahwa rubrik penskoran yang telah dikembangkan baik dan dapat digunakan dengan sedikit revisi.Berdasarkan hasil analisis validitas maka dapat disimpulkan bahwa rubrik penskoran untuk menilai kinerja praktikum hukum ohm menurut penilaian ahli telah memenuhi kriteria kevalidan, dengan kategori sangat baik. Dari penilaian ahli (validasi) diperoleh koreksi, kritik, dan saransaran yang selanjutnya merupakan bahan pertimbangan untuk merevisi perangkat.

Hasil perhitungan indeks kesepahaman antara dua validator memberikan nilai $\mathrm{R}=0,98$. Indeks kesepahaman kedua validator terhadap masing-masing perangkat, telah memenuhi kriteria perangkat yang baik yaitu lebih besar dari 0,75. Kedua validator memberikan kesimpulan bahwa rubrik penskoran yang telah dikembangkan baik dan dapat digunakan dengan sedikit revisi.Berdasarkan hasil analisis validitas maka dapat disimpulkan bahwa rubrik penskoran untuk menilai kinerja praktikum rangkaian seri resistor menurut penilaian ahli telah memenuhi kriteria kevalidan, dengan kategori sangat baik.Dari penilaian ahli (validasi) diperoleh koreksi, kritik, dan saran-saran yang selanjutnya merupakan bahan pertimbangan untuk merevisi perangkat.

Hasil perhitungan indeks kesepahaman antara dua validator memberikan nilai $\mathrm{R}=0,97$. Indeks kesepahaman kedua validator terhadap masing-masing perangkat, telah memenuhi kriteria perangkat yang baik yaitu lebih besar dari 0,75. Kedua validator memberikan kesimpulan bahwa rubrik penskoran yang telah dikembangkan baik dan dapat digunakan dengan sedikit revisi.Berdasarkan hasil analisis validitas maka dapat disimpulkan bahwa rubrik penskoran untuk menilai kinerja praktikum rangkaian parallel resistor menurut penilaian ahli telah memenuhi kriteria kevalidan, dengan kategori sangat baik.Dari penilaian ahli (validasi) diperoleh koreksi, kritik, dan saran-saran yang selanjutnya merupakan bahan pertimbangan untuk merevisi perangkat.

Hasil validasi dari pakar/ahli memperlihatkan bahwa rata skor berada pada kategori sangat baik. Dari penilaian tersebut, maka dapat disimpulkan bahawa instrumen ini telah memenuhi kriteria kevalidan dengan sedikit revisi. Penyempurnaan selanjutnya dilakukan berdasarkan penilaian pakar/ahli terdapat beberapa catatan perbaikan yang mencakup isi pernyataan, susunan kalimat serta rubrik penskorannya.

Dari hasil analisis yang dilakukan untuk penilaian praktisi terhadap perangkat yang telah dikembangkan, diperoleh informasi yang hampir sama dengan perolehan dari penilaian pakar. Hal ini menunjukkan bahwa, pakar/ahli dan praktisi telah sepakat mengatakan bahwa perangkat yang telah dikembangkan dapat digunakan sebagai alat untuk menilai kinerja praktikum IPA.

\section{Hasil Simulasi dan Uji Keterbacaan Perangkat Kinerja Praktikum}

Kegiatan simulasi bertujuan untuk melihat apakah perangkat penilaian kinerja praktikum dapat diimplementasikan. Sedangkan uji keterbacaan perangkat kinerja praktikum bertujuan untuk memperoleh saran dari mahasiswa dan dosen yang berkaitan dengan kejelasan kalimat (keterbacaan) dan bahasa yang digunakan pada perangkat kinerja praktikum yang dikembangkan. Kegiatan simulasi dilaksanakan di kelas. Kegiatan simulasi dilakukan untuk kegiatan praktikum Hukum Ohm. Pada simulasi untuk 
pelaksanaan praktikum Hukum Ohm, dosen yang juga peneliti dalam melaksanakan pembelajaran, mahasiswa terkendala/bingung apa yang harus dilakukan. Untuk itu, dosen mengambil peran khususnya dalam pemberian petunjuk pelaksanaan praktikum hukum ohm, namun secara umum setiap langkah dalam kegiatan praktikum hukum Ohm dapat dilaksanakan sesuai dengan rentang waktu yang telah direncanakan. Untuk mengatasi perasaan kaku dari mahasiswa dan dosen maka melakukan latihan mengajar berulang-ulang di luar kelas.Atas pertimbangan tersebut maka peneliti memutuskan simulasi cukup dilaksanakan hanya satu kali untuk praktikum hukum ohm, dengan catatan, dosen yang juga peneliti dalam kegiatan selanjutnya telah menguasai dan siap untuk melaksanakan kegiatan yang telah dirancang.

Sedangkan berdasarkan hasil uji keterbacaan pada mahasiswa, revisi terhadap buku penuntun dan prangkat kinerja praktikum, hanya sebatas pada kesalahan penulisan dan kesalahan tanda baca, sudah mampu memahami apa yang dimaksud pada penuntun praktikum. Dari hasil diskusi dengan pengamat, secara umum mereka telah memahami cara pengisian lembar observasi, dan angket penelitian, namun untuk menyempurnakan penuntun, tetap dilakukan perbaikan berdasarkan masukan dari semua pengamat. Berdasarkan saran tersebut maka draft awal perangkat kemudian direvisi, untuk mendapatkan perangkat yang siap diujicobakan.

\section{Deskripsi Hasil Uji Coba Perangkat Penilian Kinerja Praktikum}

Setelah draft awal direvisi, berdasarkan hasil validasi dan uji simulasi serta keterbacaan, maka hasil revisi tersebut kemudian diujicobakan di kelas. Tujuan uji coba ini untuk mendapatkan masukan dari mahasiswa dan pengamat. Hasil uji coba tersebut kemudian dianalisis yang selanjutnya dijadikan pertimbangan dalam melakukan revisi terhadap perangkat kinerja praktikum.

Subjek uji coba perangkat ini adalah mahasiswa peserta mata kuliah konsep dasar IPA Semester ganjil tahun pelajaran 2019/2020 dengan jumlah 30 orang dengan kemampuan akademik yang beragam, ada yang berkemampuan tinggi, sedang dan rendah.
Rancangan awal perangkat kinerja praktikum (Draft awal) di validasi oleh ahli dan praktisi.Hasil validasi ahli dan praktisi dijadikan sebagai bahan pertimbangan untuk merevisi perangkat kinerja praktikum. Selanjutnya berdasarkan hasil simulasi dan uji keterbacaan, perangkat direvisi kembali, kemudian diujicobakan di kelas.

\section{Uji keefektifan perangkat pembelajaran}

Pada bagian sebelumnya, telah dikemukakan hasil uji validan perangkat kinerja praktikum. Selanjutnya akan dideskripsikan hasil uji keefektifan. Perangkat di katakan efektif jika memenuhi keempat kriteria yang telah ditetapkan, yang diantaranya adalah; (1) data tentang respon dosen (teman sejawat) terhadap perangkat penilaian kinerja praktikum (uji keterbacaan) berada pada kategori minimal baik; (2) hasil lembar pengamatan penggunaan perangkat penilaian kinerja praktikum yang diisi oleh pengamat minimal terlaksana sebagian; (3) data nilai kinerja praktikum mahasiswa dapat dideskripsikan sesuai dengan kriteria yang dinilai dan; (4) respon mahasiswa terhadap terhadap perangkat pembelajaran (penuntun praktikum) positif.

\section{Respon dosen (teman sejawat) terhadap perangkat penilaian kinerja praktikum}

Dari hasil analiis berdasarkan data hasil penelitian tentang respon dosen terhadap perangkat penilaian kinerja praktikum terkait dengan uji keterbacaan perangkat yaitu perangkat penilaian kinerja praktikum beserta rubrik penskorannya diperoleh informasi bahwa, seluruh item penilaian yang digunakan dalam format penilaian kinerja praktikum fisika dan rubrik penskorannya dapat digunakan dan berada pada kategori sangat baik. Untuk itu, maka perangkat yang telah dihasilkan dapat digunakan untuk menilai kinerja praktikum mahasiswa dan telah memenuhi kriteri yang telah ditetapkan.

\section{Hasil lembar pengamatan penggunaan perangkat penilaian kinerja praktikum}

Dari hasil analisis berdasarkan data hasil penelitian diperoleh informasi bahwa, seluruh item penilaian yang digunakan dalam format penilaian kinerja praktikum fisika dan rubrik penskorannya dapat digunakan dan berda pada kategori 
terlaksana seluruhnya oleh kedua praktisi.Hal ini juga diperkuat oleh adanya penilaian secara umum terhadap semua perangkat, yang keduanya berada pada kategori sangat baik.Untuk itu, maka perangkat yang telah dihasilkan dapat digunakan untuk menilai kinerja praktikum mahasiswa, dan memenuhi kriteria yang telah ditetapkan.

\section{Data nilai kinerja praktikum mahasiswa}

Hasil analisis deskriptif skor tes pencapaian kompetensi mahasiswa dapat dilihat pada Tabel 1. Berdasarkan tabel 1 tersebut, maka dapat diperoleh informasi bahwa, nilai rata-rata kinerja praktikum fisika mahasiswa tertinggi adalah pada praktikum hukum ohm. Dari hasil analisis diperoleh informasi bahwa masih terdapat skor rata-rata rendah yang diperoleh mahasiswa khususnya pada indikator kemampuan membuat latar belakang, membuat daftar pustaka, dan membuat pembahasan.Hal ini dapat disebabkan oleh mahasiswa belum terbiasa untuk menyusun laporan hasil praktikum. Hal ini tidak terlepas dari kurangnya kuantitas pelaksanaan praktikum yang dilakukan. Untuk itu, diperlukan pembiasaan melalui kegiatan praktikum.

Tabel 1: Statistik nilai akhir penilaian kinerja praktikum

\begin{tabular}{cccc}
\hline \multirow{2}{*}{ Parameter } & \multicolumn{3}{c}{ Nilai Statistik } \\
\cline { 2 - 4 } & Hukum Ohm & Rangkaian Seri & Rangkaian Paralel \\
\hline Subjek Penelitian & 30 & 30 & 30 \\
\hline Skor ideal & 100 & 100 & 100 \\
\hline Rata-rata & 77 & 73 & 71 \\
\hline Standar Deviasi & 5.94 & 7.35 & 4.61 \\
\hline Rentang Skor & 25 & 35 & 65 \\
\hline Skor Minimum & 60 & 60 & 85 \\
\hline Skor Maksimum & 85 & 95 & 1 \\
\hline
\end{tabular}

Skor 30 orang mahasiswa yang mengikuti kegiatan pembelajaran untuk ketiga unit percobaan berada pada rentang $65-84$. Dengan demikian, dapat disimpulkan bahwa rata-rata kinerja praktikum IPA mahasiswa berada pada kategori tinggi. Dari hasil penilaian yang dilakukan dengan menggunakan perangkat yang telah dihasilkan maka dapat diperoleh informasi tentang nilai kinerja praktikum yang diberikan melalui analisis deskripsi yang disajikan dalam bentuk distribusi frekuesi dan persentase. Berdasarkan hal tersebut, maka data nilai kenerja yang dihasilkan dari perangat penilaian yang digunakan telah dapat mendeskripsikan nilai kinerja praktikum mahasiswa, sehingga memenuhi kriteria yang telah ditetapkan.

\section{Respon mahasiswa terhadap Penuntun Praktikum}

Instrumen untuk memperoleh data respon mahasiswa adalah angket respon mahasiswa. Dari hasil analisis diperoleh bahwa 93,33 persen mahasiswa memberikan respon positif terhadap penuntun praktikum. Dengan demikian, mahasiswa merespon positif perangkat penilaian kinerja praktikum sehingga tidak perlu diadakan perbaikan/revisi terhadap perangkat yang didasarkan pada respons mahasiswa.

Berikut adalah uraian pembahasan dalam penelitian ini.

\section{Kevalidan}

Hasil analisis data terhadap penilaian validator terhadap perangkat pembelajaran menunjukkan bahwa rata-rata penilaian ahli terhadap semua perangkat dilihat dari setiap indikator yang akan dinilai dalam kineraja praktikum adalah sangat baik. Meskipun demikian, namun masih terdapat penilaian dari pakar/ahli yang belum mencapai angka maksimal, untuk itu dilakukan revisi berdasarkan saran, koreksi dan pertimbangan validator dan peneliti.Setelah dilakukan revisi maka perangkat ini dapat digunakan dalam menilai kinerja praktikum fisika di kelas.

\section{Keefektifan perangkat penilaian}

Hasil penilaian ahli terhadap perangkat penilaian kinerja paraktikum menyatakan bahwa 
perangkat layak digunakan dalam menilai kinerja praktikum fisika. Sedangkan secara empirik, berdasarkan hasil analisis terhadap hasil pengamatan terhadap penggunaan perangkat penilaian kinerja praktikum beserta pedoman penskorannya oleh praktisi atau pengguna menyatakan bahwa seluruh komponen dalam format penilaian kinerja dan rubriknya dapat dieksekusi/dilaksanakan dan dipahami. Sehingga dapat disimpulkan bahwa.perangkat telah memenuhi kriteria terlaksana seluruhnya dan dapat digunakan.

Hasil analisis menunjukkan bahwa, seluruh aspek yang ditanyakan dalam pelaksanaan kegiatan pembelajaran dengan menggunakan penuntun praktikum, direspons positif oleh mahasiswa seluruh aspek yang ditanyakan direspons positif oleh mahasiswa, sehingga dapat disimpulkan bahwa mahasiswa memberi respon positif terhadap kegiatan pembelajaran dengan menggunakan penuntun praktikum.

Keempat kriteria kefektifan yang telah ditetapkan, yaitu; (1) data tentang respon dosen (teman sejawat) terhadap perangkat penilaian kinerja praktikum (uji keterbacaan) berada pada kategori minimal baik; (2) hasil lembar pengamatan penggunaan perangkat penilaian kinerja praktikum yang diisi oleh pengamat minimal terlaksana sebagian; (3) data nilai kinerja praktikum mahasiswa dapat dideskripsikan sesuai dengan kriteria yang dinilai dan; (4) respon mahasiswa terhadap terhadap perangkat pembelajaran (penuntun praktikum) positif. Sehingga dilihat dari kriteria efektif, maka penilaian kinerja praktikum beserta rubrik/pedoman penskorannya kriteria efektif, sehingga dapat digunakan.

\section{Temuan khusus}

Proses pembelajaran mengkondisikan mahasiswa untuk belajar melalui serangkaian informasi dalam penuntun praktikum, dan informasi tambahan yang disampaikan oleh dosen berdasarkan tahap-tahap yang telah direncanakan secara matang. untuk memperoleh konsep, keterampilan, dan menerapkan konsep atau keterampilan tersebut dalam menyelesaikan masalah yang diberikan.

Hasil penilaian menunjukkan bahwa perangkat penilaian telah memenuhi kriteria valid, dan efektif. Penilaian ahli terhadap seluruh perangkat sangat baik. Keseluruhan komponen perangkat dapat diaksekusi dan dipahami cara penggunaaannya. Dosen dapat menerapkan/ menggunakan perangkat dengan tingkat kemampuan berada pada kategori baik, mahasiswa merespon positif terhadap penuntun praktikum.

\section{Kendala-kendala}

Kendala yang dialami selama kegiatan pengembangan, baik sebelum maupun dalam kegiatan uji coba perangkat penilaian kinerja.Kendala-kendala yang dimaksud dikemukakan sebagai berikut adalah; 1) diperlukan keberlanjutan untuk menguasai cara penggunaan perangkat yang dihasilkan; 2) terdapat beberapa mahasiswa yang memiliki perilaku tidak sesuai dengan kriteri yang diharapkan muncul dalam penilaian. Untuk itu diperlukan kajian lebih mendalam tentang hal tersebut. Perilaku tersebut antara lain: (a) malas mengajukan pertanyaan jika tidak mengerti, (b) kurang mempersiapkan diri mengikuti pelajaran; dan 3) pada awal uji coba, mahasiswa masih terkadang bingung dengan apa yang harus dikerjakan, hal ini dapat disebabkan karena mahasiswa belum terbiasa terhadap model pembelajaran yang diberikan, serta jarangnya dilakukan praktikum di kelas, dan cara mengajar dosen, dan persiapan dosen yang belum maksimal.

\section{SIMPULAN DAN SARAN}

Berdasarkan hasil penelitian, maka dapat disimpulkan bahwa perangkat penilaian kinerja praktikum tentang Hukum Ohm, Rangkaian Seri dan Rangkaian Paralel masing-masing beserta rubriknya telah dihasilkan memenuhi kriteri valid dan efektif serta dapat dilaksanakan dengan baik oleh pengguna.

Uji coba penggunaan perangkat hanya dilakukan di Prodi. PGSD FIP UNM, namun perangkat ini juga dapat digunakan pada Mahasiswa lain yang memprogramkan mata kuliah konsep dasar IPA. Perangkat kinerja praktikum yang telah dihasilkan terbatas hanya pada beberapa unit praktikum, untuk itu disarankan kepada pengguna untuk mengembangkan perangkat yang sama pada unit praktikum lain.

Sebelum menerapkan perangkat ini, diharapkan kepada pengguna untuk mempelajari, memahami, dan melakukan eksplorasi awal terhadap perangkat ini demi kelancaran dalam 
penggunaannya. Untuk memperoleh perangkat pembelajaran yang lebih baik disarankan kepada pihak yang berkepentingan untuk melakukan penyebaran perangkat pembelajaran ini pada skala yang lebih luas.

\section{DAFTAR RUJUKAN}

Arikunto, Suharsimi. 2002. Dasar-Dasar Evaluasi Pendidikan. Jakarta: Bumi Aksara.

Asiah. 2019. Penggunaan Pendekatan Keterampilan Proses Untuk Meningkatkan Pemahaman Siswa tentang Konsep Energi Bunyi Di Kelas VI SD Negeri 110 Pompanua Kabupaten Bone. JIKAP PGSD: Jurnal Ilmiah Ilmu Kependidikan, 3 (2): 108-118. DOI: http://doi.org/ 10.26858/jkp.v3i2.9105

Borich, G. D. 1994. Observation Skills for Effectiv Teaching, Second Edition. New York: Macmillan Publishing Company

Djaali \& Pudji Mujiono. 2008. Pengukuran dalam bidang pendidikan. Jakarta: Grasindo.

Emma, Woodley. 2009. Practical work in school science - why is it important?. School Science Review, Vol 91 pp. 49-52

Lazarowitz, R. and Tamir P. 1994. Research on using laboratory instruction in science. In: Gabel D. (ed) Handbook of research on science teaching and learning ( $\mathrm{pp}$ 94128). MacMillan, New York.

Lilyana, A. T. 2015. Pengembangan Instrumen Penilaian Karakter pada Pembelajaran Biologi Di SMA Negeri 1 Demak. Semarang: Universitas Negeri Semarang

Poerwanti, E., et.al. 2008. Asesmen Pembelajaran SD, Bahan Ajar Cetak. Jakarta: Ditjen Dikti-Depdiknas.

Purwanto, Ngalim. 2002. Prinsip-prinsip dan Teknik Evaluasi Pengajaran. Bandung: PT Remaja Rosdakarya.

Sabtiawan, Yuanita, \& Rahayu. 2013. Evaluation of the Effectiveness of Authentic Assessment on Students' Attitudes. Pendidikan Sains Pascasarjana Universitas Negeri Surabaya, Vol 3 (1) pp.282-285

Schraw, G. and Lehman, S. 2001. "Situational interest: A review of the literature and directions for future research". Educational Psychology Review, Vol. 13, pp.23-52.
Stufflebeam, D. L. 2002. The CIPP Model For Evaluation, dalam Daniel L. Stufflebeam, dkk. (eds), Evaluation in Education and Human Service, Boston: Kluwer Academic Publisher. 